\title{
Assessment of Online Learning Application for Health Education
}

https://doi.org/10.3991/ijoe.v15i12.11157

\author{
Hery H. Muljo, Anzaludin S. Perbangsa, Bens Pardamean ( $\left.{ }^{\varpi}\right)$ \\ Bina Nusantara University, Jakarta, Indonesia \\ bpardamean@binus . edu
}

\begin{abstract}
Online learning has become a model, learning strategies, and the preferred channel in education around the world because it is not restricted by time and place. The development of online learning in supporting the success of health education programs for early detection of cervical cancer is the right solution to improve health workers knowledge. To measure user acceptance of the online learning applications, the study used Technology Acceptance Model (TAM) approach. Data collected from questionnaires then analyzed by calculating the frequency (proportion) of the total value, the interpretation of a score by looking for index $\%$ and interval. The final result of the calculation shows that all respondents agreed and strongly agreed with all four factors measured. The conclusions are the users believe that the use of learning online applications can reduce the task effort, improve job performance, give positive idea to use the technology, and consciously and expressed desire to run the online learning process in the future.
\end{abstract}

Keywords - Early detection, cervical cancer, online learning, Technology Acceptance Model

\section{Introduction}

Cancer is the number two cause of death in the world. The cancer research group from the World Health Organization (WHO) states, there are at least 18.1 million cases of cancer with a total death of 9.6 million in 2018. In Indonesia, the 2018 Basic Health Research (Riskesdas) shows the prevalence of cancer increased from 1.4 percent in 2013 became 1.8 percent in 2018. According to Globocon data in 2018, new cases of cervical cancer in Indonesia reached 32,469. Launched Tribunnews, the death rate from cervical cancer reached 18,279 per year. This means that there are around 50 Indonesian women died from cervical cancer each year. This figure jumped sharply compared to the Globocon data in 2012 which stated that 26 Indonesian women die of cervical cancer every year. Another case is cervical cancer, the number of people with cervical cancer cases is ranked second after breast cancer in the world. Nearly $80 \%$ are found in developing countries. Based on WHO data, $99 \%$ of cervical cancers are associated with infection with human papillomavirus (HPV) in the genitals [1]. 
In 2005, with the establishment of the Directorate of Non-Communicable Diseases, Indonesia had begun a cancer prevention program with priority for breast cancer and cervical cancer. This step was formalized by the issuance of Minister of Health Decree No. $1163 / \mathrm{MenKes} / \mathrm{SK} / 2007$, namely the establishment of a working group to control cervical cancer and breast cancer [2]. Other efforts that have been made by the Indonesian government are counseling. Counseling is one of the most sought after health promotion efforts by health cadres and medical personnel, but this business has problems due to the lack of knowledge of breast cancer and cervical cancer [3]. Other health promotion efforts are carried out in the form of formal training carried out nationally but require funding that is not small and takes a long time. For this reason, a new step is needed in the form of using services such as telemedicine which are proven to reduce costs significantly [4]. The development of this online learning program for cervical cancer early detection is offered to answer these obstacles.

Online learning is a learning channel that is partially or entirely conveyed via the Internet [5] where students are away from the teacher and can access learning materials by utilizing information technology [6]. Technology-based e-learning produces materials for learning, teaching students and also arranges courses in an organization [7]. Online learning can shape students to become more independent [8] and the regulation of learning time can be fully utilized, as well as reviewing material can be done regularly [9].

\subsection{Benefit of online learning}

The real benefit of online learning is to reach wider target participants from different geographical, time, social and cultural background [10]. Online learning is also useful for participants in maintaining quality of life, increase independence, enrich medical knowledge, and improve health conditions [11]. Institutions do not need to provide classrooms, desks and chairs should be placed [12]. Online learning is also creating learning opportunities for people living in remote and inaccessible locations, increasing the number of students, enabling broader communications, and lowering learning operational cost [13], as well as improving academic success by increasing the number of students and also establishing new institutions in inaccessible areas [14].

Online learning is also considered to be very helpful and beneficial for "disability student". This is proved by the level of achievement of "disability student" which equaled the average of other students [15]. The resulting quality of the learning process of online learning has similar results compared with face to face learning [16]. In addition, the use of audio/video in the online learning will strengthen the relationship between the participants, especially women [17].

\subsection{Factors success}

There are two important factors in determining the success of online courses namely self-regulation which is a key component and motivation as a support for the success of online courses [18]. Another factor that determines the success of online 
courses is interaction and communication. Interaction and communication lead to increased student satisfaction and motivation. Interaction can occur in three main areas, namely interactions between students and instructors; students and other students; and students and content [19]. These four factors are determinants of the success of online courses.

\subsection{The challenge of online learning for learners}

According to Kebritchi, Lipschuetz and Santiague [20], there are four challenges for online learning for students, namely expectations, readiness, identity, and participation.

Learners' expectations: Learners' expectations can be a challenge where the process of online courses may be less effective [21]. One example is when learners expect too much for instant feedback. To communicate all regulations and policies at the very beginning of the learning process is considered a good strategy to minimize learners' expectation.

Learners' readiness: Learners' readiness to enroll in online course may become the big challenge for learners [22][23]. Since not all learners are self-motivated and self-directed, some of them may not be successful in following the whole process of online courses. Learners' readiness to actively participate in online courses can be established by having technical skills related to operating computer as well as the Internet [24], their perception and mindset towards Internet [25], their cultural and non-English backgrounds [26], dan their time management skills [27][28].

Learners' identity: Feeling isolated and disconnected in online courses will affect the learning process [29], thus it is considered essential for learners to establish a shared sense of belonging, purpose, and norms [30][31]. The development of Web of Identity model with five components of technical, political, structural, cultural, and performance to succeed in online settings has a particular purpose to help learners achieve a sense of identity [30].

Learners' participation: The next challenge in implementing online courses is learners' participation and involvement. Learners spend most of their time to read rather than to write [32][33] and also to listen and pay attention to the on-going online discussion [33].

\subsection{Problem of research}

Two supporting studies have been conducted related to online learning for cancer early detection. Firstly, the development of the content and design of Learning Management Systems (LMS) that is suitable for the dissemination of information for early detection of cervical cancer which resulted in the formation of the definition of the system, the need for health cadres, system requirements, and the development of content [34]. Second, analysis and design, system prototype, and testing using ADDIE (Analysis, Design, Develop, Implement, and Evaluate) framework as one of the System Development Life Cycle (SDLC) which resulted in the formation of online learning applications [35]. 
This research is a continuation of previous research. This study focuses on the process of implementing online learning applications at Puskesmas and assesses the level of acceptance of online learning applications by users, namely medical personnel and health cadres by using the Technology Acceptance Model (TAM) consisting of research questions. The Process of Assessing User acceptance of technology is very important because of achieving system implementation and winning success [36] and is an important measure for measuring system success [37].

\subsection{Research focus}

Technology Acceptance Model (TAM) is a research model for predicting the use and acceptance of information systems and technology by individual users [38]. The aim is to explain and predict acceptance users against an information system. The level of user acceptance of the application online learning is an important factor in application development. In this study used data by Likert scale to evaluate the level of acceptance. Likert scale is a psychometric scale used in the questionnaire and is a technique used to evaluate a program.

\section{Methodology}

\subsection{General background of research}

The data collected are primary data. Primary data were collected by distributing a questionnaire at the time of the implementation of online learning applications in health centers with the aim of obtaining data on user acceptance of online learning application that consists of four constructs, including perceived ease of use, perceived usefulness, attitude toward using, and intention to use.

\subsection{Sample of research}

The study obtained data by distributing a questionnaire to 27 health workers in health centers in West Jakarta region, Indonesia.

\subsection{Instrument and procedures}

In this study, TAM was used as a basic model to explain the main factors of user behavior on user acceptance of online learning application that aims to help organizations use and manage existing information technology resources and increase overall effectiveness. There were four main factors measured which were perceived ease of use, perceived usefulness, attitude toward using, and behavioral intention to use.

The collected data were analyzed using Likert scaling procedures known as the Likert's Summated Rating, and is divided into four categories: strongly agree, agree, disagree and strongly disagree. Figure 1 describes the score calculation method. 


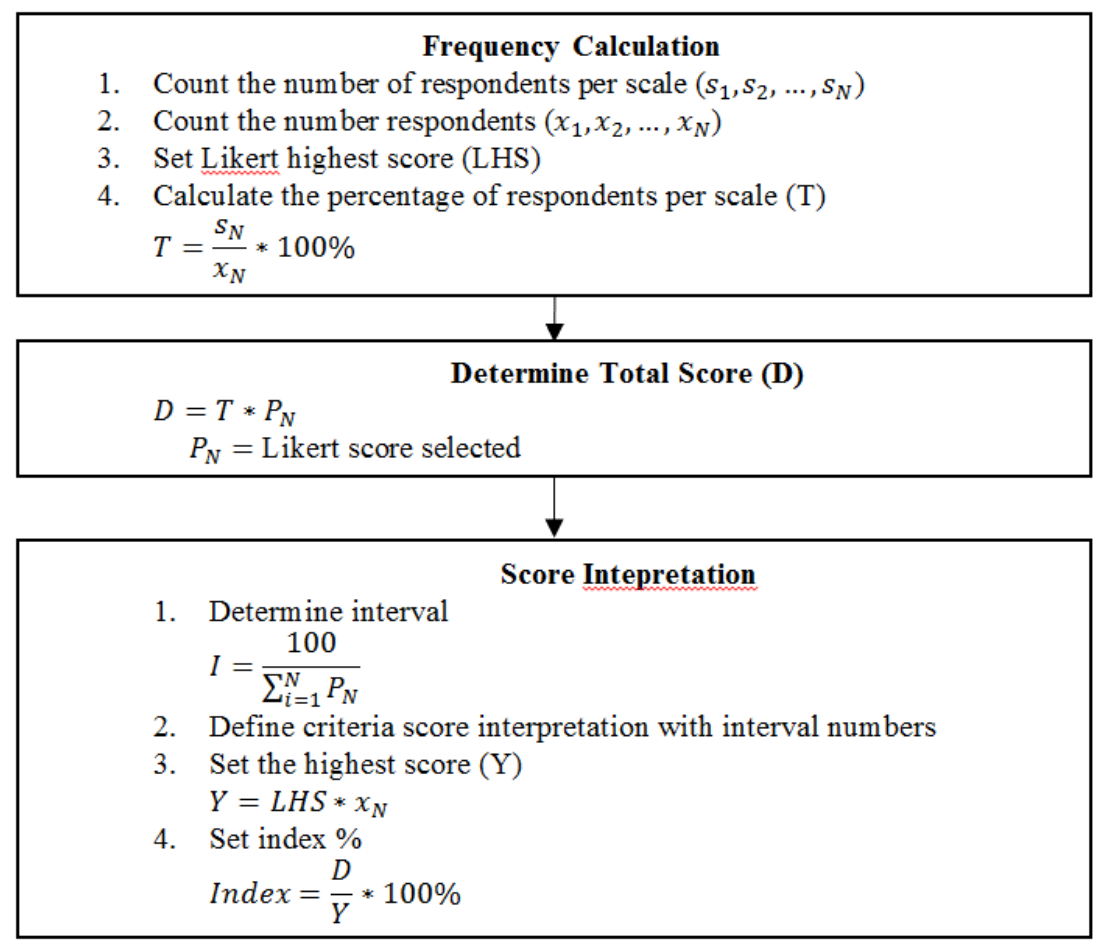

Fig. 1. Score Calculation Method

\subsection{Data analysis}

The Likert scale was used in the questionnaire to measure the perception of the user acceptance of online learning application using categories 1 to 4 (1=strongly disagree, $2=$ disagree, $3=$ agree and $4=$ strongly agree). All four categories were then translated to four intervals ranging from $0 \%-24.99 \%$ (strongly disagree), $25 \%-49.99 \%$ (disagree), 50\% - 74.99\% (agree), and 75\% - 100\% (strongly agree). These intervals were aimed to gauge how satisfied the respondents' perception of the design of the questionnaire.

\section{Results}

Perceived Ease of Utilizing indicator gauged the users' perception on the early detection of cervical cancer online learning that is convenient to utilize and is not a burden for the user. Table 1 details the four questions that represent Perceived Ease of Utilizing factor along with the Likert scores response and its respective equivalence intervals. 
Table 1. Perceived Ease of Utilizing Design

\begin{tabular}{|l|l|c|}
\hline \multicolumn{1}{|c|}{ Questions } & \multicolumn{1}{|c|}{ Response } & \multicolumn{1}{c|}{ Interval } \\
\hline $\begin{array}{l}\text { Q1: Cervical cancer early detection online learning is } \\
\text { ease to utilize. }\end{array}$ & \\
\cline { 1 - 2 } $\begin{array}{l}\text { Q2: Learning by using cervical cancer early detec- } \\
\text { tion online learning will be beneficial for me. }\end{array}$ & $\begin{array}{l}\text { 4. Strongly agree } \\
\text { 3. Agree }\end{array}$ & $75 \%-100 \%$ \\
\cline { 1 - 2 } $\begin{array}{l}\text { Q3: Interaction with the cervical cancer early detec- } \\
\text { tion online learning is clear and can be understood. }\end{array}$ & $\begin{array}{l}\text { 2. Disagree } \\
\text { 1. Strongly disagree }\end{array}$ & $50 \%-74.99 \%$ \\
\cline { 1 - 2 } $\begin{array}{l}\text { Q4: Easy for me to utilize cervical cancer early } \\
\text { detection online learning. }\end{array}$ & & $25 \%-49.99 \%$ \\
\hline
\end{tabular}

Based on the calculation result shown in Table 2, the Likert scale questions Q1 and Q2 have the total scores of 80 and 82, respectively. Meanwhile, question Q3 has a total score of 73 and followed by question Q4 with a total score of 77.

Table 2. Perceived Ease of Utilizing Scores

\begin{tabular}{|l|c|c|c|c|c|c|c|c|c|}
\hline \multirow{3}{*}{ Response } & \multicolumn{4}{|c|}{ Total Respondents $\left(\boldsymbol{x}_{\boldsymbol{N}}\right)$} & Likert Score Options & \multicolumn{4}{c|}{$\begin{array}{c}\text { Total Likert Score } \\
\left(\boldsymbol{x}_{\boldsymbol{N}} * \boldsymbol{P}_{\boldsymbol{N}}\right)\end{array}$} \\
\cline { 2 - 12 } & $\boldsymbol{Q 1}$ & $\boldsymbol{Q 2}$ & $\boldsymbol{Q 3}$ & $\boldsymbol{Q 4}$ & $\boldsymbol{( \boldsymbol { P } _ { \boldsymbol { N } } )}$ & $\boldsymbol{Q 1}$ & $\boldsymbol{Q 2}$ & $\boldsymbol{Q 3}$ & $\boldsymbol{Q 4}$ \\
\hline Strongly agree & 3 & 2 & 2 & 1 & 4 & 12 & 8 & 8 & 4 \\
\hline Agree & 20 & 24 & 15 & 21 & 3 & 60 & 72 & 45 & 63 \\
\hline Disagree & 4 & 1 & 10 & 5 & 2 & 8 & 2 & 20 & 10 \\
\hline Strongly disagree & 0 & 0 & 0 & 0 & 1 & 0 & 0 & 0 & 0 \\
\hline$\sum$ & 27 & 27 & 27 & 27 & & 80 & 82 & 73 & 77 \\
\hline
\end{tabular}

The total Likert score for each question in Table 2 can be associated with its result index $\%$ in Table 3 to show the interpretation result index \%. Apparently, Q2 has the highest of interpretation result index \% among the four-question of Perceived Ease of Utilizing factor. It earned a score of 76 which equates to "strongly agree". Additionally, for the remaining questions, each scored an "agree" response.

Table 3. Perceived Ease of Utilizing Interpretation Result Index \%

\begin{tabular}{|c|c|c|c|l|}
\hline Question & Total Likert Score & $\begin{array}{c}\text { Total Score } \\
\text { (Maximum) }\end{array}$ & \multicolumn{2}{|c|}{ Result Index \% } \\
\hline Q1 & 80 & 108 & 74 & Agree \\
\hline Q2 & 82 & 108 & 76 & Strongly agree \\
\hline Q3 & 73 & 108 & 68 & Agree \\
\hline Q4 & 77 & 108 & 71 & Agree \\
\hline
\end{tabular}

Thus, it can be concluded that the respondents are much agree that online learning applications for early detection of cervical cancer is easy to use and is not a burden for the users.

The next indicator is Perceived of Usefulness. It is used to determine whether the use of cervical cancer early detection online learning will improve work performance for those who use it. Perceived of Usefulness design consists of four questions as shown in Table 4, each with its Likert score response and percentage interval. 
Table 4. Perceived of Usefulness Design

\begin{tabular}{|l|l|c|}
\hline \multicolumn{1}{|c|}{ Questions } & \multicolumn{1}{|c|}{ Response } & Interval \\
\hline $\begin{array}{ll}\text { Q5: Using cervical cancer early detection online learning will } \\
\text { increase the knowledge about cervical cancer symptoms. }\end{array}$ & & \\
\cline { 1 - 1 } $\begin{array}{l}\text { Q6: Using cervical cancer early detection online learning will } \\
\text { increase the knowledge about cervical cancer causes. }\end{array}$ & 4. Strongly agree & $75 \%-100 \%$ \\
\cline { 1 - 2 } $\begin{array}{l}\text { Q7: Using cervical cancer early detection online learning will } \\
\text { increase the success of the dissemination program. }\end{array}$ & 2. Disagree & $50 \%-74.99 \%$ \\
\cline { 1 - 2 } $\begin{array}{l}\text { Q8: Using cervical cancer early detection online learning will } \\
\text { prevent cervical cancer occurrence. }\end{array}$ & & $25 \%-49.99 \%$ \\
\hline
\end{tabular}

The reckoning result of Perceived of Usefulness, as shown in Table 5, concludes that almost all questions have the total scores more than 80 except for Q7. Q5 has the highest score among all questions with the score of 88 followed by Q6 and Q8, with the total scores of 86 and 82 , respectively. Q7 has the total score of 79, just slightly below 80 .

Table 5. Perceived of Usefulness Scores

\begin{tabular}{|l|c|c|c|c|c|c|c|c|c|}
\hline \multirow{2}{*}{ Response } & \multicolumn{3}{|c|}{$\begin{array}{c}\text { Total Respondents } \\
\left(\boldsymbol{x}_{\boldsymbol{N}}\right)\end{array}$} & \multicolumn{4}{c|}{$\begin{array}{c}\text { Likert Score } \\
\text { Options }\end{array}$} & \multicolumn{4}{c|}{$\begin{array}{c}\text { Total Likert Score } \\
\left(\boldsymbol{x}_{\boldsymbol{N}} * \boldsymbol{P}_{\boldsymbol{N}}\right)\end{array}$} \\
\cline { 2 - 11 } & $\boldsymbol{Q 5}$ & $\boldsymbol{Q 6}$ & $\boldsymbol{Q 7}$ & $\boldsymbol{Q 8}$ & $\left(\boldsymbol{P}_{\boldsymbol{N}}\right)$ & $\mathbf{Q 5}$ & $\mathbf{Q 6}$ & $\boldsymbol{Q 7}$ & $\boldsymbol{Q 8}$ \\
\hline Strongly agree & 8 & 5 & 2 & 3 & 4 & 32 & 20 & 8 & 12 \\
\hline Agree & 18 & 22 & 21 & 22 & 3 & 54 & 66 & 63 & 66 \\
\hline Disagree & 1 & 0 & 4 & 2 & 2 & 2 & 0 & 8 & 4 \\
\hline Strongly disagree & 0 & 0 & 0 & 0 & 1 & 0 & 0 & 0 & 0 \\
\hline$\sum$ & 27 & 27 & 27 & 27 & & 88 & 86 & 79 & 82 \\
\hline
\end{tabular}

As summarized in Table 6, except for Q7, all questions for Perceived of Usefulness factor have the total scores more than 80 which were classified as "strongly agree". For Q7, it has the lowest total score that was translated to just "agree".

Table 6. Perceived of Usefulness Interpretation Result Index \%

\begin{tabular}{|c|c|c|l|l|}
\hline Question & Total Likert Score & $\begin{array}{c}\text { Total Score } \\
\text { (Maximum) }\end{array}$ & \multicolumn{2}{|c|}{ Result Index \% } \\
\hline Q5 & 88 & 108 & 81 & Strongly agree \\
\hline Q6 & 86 & 108 & 80 & Strongly agree \\
\hline Q7 & 79 & 108 & 73 & Agree \\
\hline Q8 & 82 & 108 & 76 & Strongly agree \\
\hline
\end{tabular}

Accordingly, the respondents strongly agreed that the online learning application on the use of early detection of cervical cancer would increase knowledge about the symptoms and causes of cervical cancer, as well as the importance of counseling, and preventing cervical cancer.

Attitude-toward-Using indicator was utilized to determine attitudes toward the use of the online learning application. It measured the form of acceptance or rejection as the result when a user uses this online learning application technology. This indicator consists of four questions as details in Table 7. 
Table 7. Attitude toward Using Design

\begin{tabular}{|c|c|c|}
\hline Questions & Response & Interval \\
\hline $\begin{array}{l}\text { Q9: I like the idea of using cervical cancer early } \\
\text { detection online learning. }\end{array}$ & \multirow{4}{*}{$\begin{array}{l}\text { 4. Strongly agree } \\
\text { 3. Agree } \\
\text { 2. Disagree } \\
\text { 1. Strongly disagree }\end{array}$} & \multirow{4}{*}{$\begin{array}{c}75 \%-100 \% \\
50 \%-74.99 \% \\
25 \%-49.99 \% \\
0 \%-24.99 \%\end{array}$} \\
\hline $\begin{array}{l}\text { Q10: I give it a good attitude in general to take ad- } \\
\text { vantage of cervical cancer early detection online } \\
\text { learning. }\end{array}$ & & \\
\hline $\begin{array}{l}\text { Q11: I believe this would be a good idea when utiliz- } \\
\text { ing cervical cancer early detection online learning for } \\
\text { independence process. }\end{array}$ & & \\
\hline $\begin{array}{l}\text { Q12: Utilizing cervical cancer early detection online } \\
\text { learning is a good idea. }\end{array}$ & & \\
\hline
\end{tabular}

All questions in Attitude-toward-Using indicator scored quite a similar score within interval of 80-82 as shown in Table 8. Q9 and Q11 have an identical total score of 81, while Q10 was the question that has the highest total score among them with the total score of 82 . Q12 was the question with the lowest total score, it only scored 80 .

Table 8. Attitude toward Using Likert Scores

\begin{tabular}{|l|c|c|c|c|c|c|c|c|c|}
\hline \multirow{2}{*}{ Response } & \multicolumn{4}{|c|}{$\begin{array}{c}\text { Total Respondents } \\
\left(\boldsymbol{x}_{\boldsymbol{N}}\right)\end{array}$} & $\begin{array}{c}\text { Likert Score } \\
\text { Options }\end{array}$ & \multicolumn{4}{c|}{$\begin{array}{c}\text { Likert Score } \\
\left(\boldsymbol{x}_{\boldsymbol{N}} * \boldsymbol{P}_{\boldsymbol{N}}\right)\end{array}$} \\
\cline { 2 - 11 } & $\mathrm{Q} 9$ & $\mathrm{Q} 10$ & $\mathrm{Q} 11$ & $\mathrm{Q} 12$ & $\left(\boldsymbol{P}_{\boldsymbol{N}}\right)$ & $\mathrm{Q} 9$ & $\mathrm{Q} 10$ & $\mathrm{Q} 11$ & Q12 \\
\hline Strongly agree & 3 & 1 & 3 & 2 & 4 & 12 & 4 & 12 & 8 \\
\hline Agree & 21 & 26 & 21 & 22 & 3 & 63 & 78 & 63 & 66 \\
\hline Disagree & 3 & 0 & 3 & 3 & 2 & 6 & 0 & 6 & 6 \\
\hline Strongly disagree & 0 & 0 & 0 & 0 & 1 & 0 & 0 & 0 & 0 \\
\hline$\sum$ & 27 & 27 & 27 & 27 & & 81 & 82 & 81 & 80 \\
\hline
\end{tabular}

Despite of the similarity of the total scores among the questions in Attitude Toward Using indicator, it turned out that the interpretation result index $\%$ of all questions did not show that similarity. Based on Table 9, Q12 that has the lowest total scores only equates to "agree" because it seems that 80 is lied on the borderline between "strongly agree" and "agree". For the remain questions, that have the total scores higher than 80 , they scored "strongly agree" response.

Table 9. Attitude Toward Using Interpretation Result Index \%

\begin{tabular}{|c|c|c|c|l|}
\hline Question & Total Likert Score & Total Score(Maximum) & \multicolumn{2}{|l|}{ Result Index \% } \\
\hline Q9 & 81 & 108 & 75 & Strongly agree \\
\hline Q10 & 82 & 108 & 76 & Strongly agree \\
\hline Q11 & 81 & 108 & 75 & Strongly agree \\
\hline Q12 & 80 & 108 & 74 & Agree \\
\hline
\end{tabular}

Hence, it can be concluded that the respondents perceived a very good attitude toward the use of cervical cancer online learning application. Almost all respondents strongly agreed that the use of this online learning application is a good idea.

The last indicator is Intention to Utilize that can be used to determine the user's propensity to use technology. This indicator consists of only three questions, slightly different from all previous indicators that have four questions for each. Table 10 shows the three questions along with the Likert scores and its respective equivalence interval. 
Table 10.

Intention to Utilize Design

\begin{tabular}{|l|l|c|}
\hline \multicolumn{1}{|c|}{ Questions } & \multicolumn{1}{|c|}{ Response } & Interval \\
\hline Q13: I intend to take advantage of cervical cancer early & & $75 \%-100 \%$ \\
detection online learning. & 4. Strongly agree & $50 \%-74.99 \%$ \\
\hline Q14: I will take advantage of cervical cancer early detec- & 3. Agree & $25 \%-49.99 \%$ \\
tion online learning while conducting dissemination. & 2. Disagree & $0 \%-24.99 \%$ \\
\hline $\begin{array}{l}\text { Q15: I intend to always take advantage of cervical cancer } \\
\text { early detection online learning }\end{array}$ & 1. Strongly disagree & \\
\hline
\end{tabular}

The calculation of the scores as can be seen in Table 11, shows relatively low total scores for all questions comparing with the three other indicators. Q13, as the question with the highest total score, only received a score of 80 . While the others two questions, Q14 and Q15 had total scores of 77 and 75, respectively.

Table 11. Intention to Utilize Likert Scores

\begin{tabular}{|l|c|c|c|c|c|c|c|}
\hline \multirow{2}{*}{ Response } & \multicolumn{3}{|c|}{ Total Respondents } & $\begin{array}{c}\text { Likert Score Op- } \\
\text { tions }\end{array}$ & \multicolumn{3}{c|}{$\begin{array}{c}\text { Likert Score } \\
\left(\boldsymbol{x}_{\boldsymbol{N}} \boldsymbol{*} \boldsymbol{*}_{\boldsymbol{N}}\right)\end{array}$} \\
\cline { 2 - 9 } & $\boldsymbol{Q 1 3}$ & $\boldsymbol{Q 1 4}$ & $\boldsymbol{Q 1 5}$ & $\left(\boldsymbol{P}_{\boldsymbol{N}}\right)$ & $\boldsymbol{Q 1 3}$ & $\boldsymbol{Q 1 4}$ & $\boldsymbol{Q 1 5}$ \\
\hline Strongly agree & 3 & 2 & 2 & 4 & 12 & 8 & 8 \\
\hline Agree & 20 & 19 & 17 & 3 & 60 & 57 & 51 \\
\hline Disagree & 4 & 6 & 8 & 2 & 8 & 12 & 16 \\
\hline Strongly disagree & 0 & 0 & 0 & 1 & 0 & 0 & 0 \\
\hline$\sum$ & 27 & 27 & 27 & & 80 & 77 & 75 \\
\hline
\end{tabular}

As reflected from the calculation in previous table, it can be summarized in Table 12 that each question in Intention to Utilize indicator scored an "agree" response.

Table 12.

Intention to Utilize Interpretation Result Index \%

\begin{tabular}{|c|c|c|c|l|}
\hline Question & Total Likert Score & $\begin{array}{c}\text { Total Score } \\
\text { (Maximum) }\end{array}$ & \multicolumn{2}{|c|}{ Result Index \% } \\
\hline Q13 & 80 & 108 & 74 & Agree \\
\hline Q14 & 77 & 108 & 71 & Agree \\
\hline Q15 & 75 & 108 & 69 & Agree \\
\hline
\end{tabular}

Therefore, it can be concluded that all respondents felt that they would likely to use the cervical cancer online learning application while conducting information dissemination. Furthermore, the most respondents agreed that they would always take advantages from the use of this application.

\section{Conclusion}

The development of cervical cancer early detection online learning application started from the needs to disseminate cancer early detection education contents that had been issued by the Ministry of Health. The dissemination program had not been widely implemented due to lack of healthcare workers and medical personnel knowledge and the high cost of information dissemination. This online learning application was a response to these challenges. It can educate new healthcare workers and medical personnel and improved their early detection of cervical cancer knowledge 
without geographical, time, physical barriers (for those with physical disabilities) and at minimum cost. The assessment results of the online learning application concluded that the application was well-accepted as well as well-perceived in its usefulness by users.

\section{Acknowledgement}

This study was funded by a Competitive Grant of the Directorate of Research and Community Services of the Republic of Indonesia's Ministry of Research, Technology, and Higher Education.

\section{References}

[1] World Health Organization, "Human papillomavirus and related cancers," Barcelona, Spain: WHO/ICO Information Centre on HPV and Cervical Cancer, 2010.

[2] B. Dwipoyono, "Kebijakan pengendalian penyakit kanker (serviks) di Indonesia," Indonesian Journal of Cancer, vol. 3, no. 3, pp. 109-116, 2009.

[3] M. S. El Hajj, \& Y. Hamid, "Breast cancer health promotion in Qatar: A survey of community pharmacists' interests and needs," International Journal of Clinical Pharmacy, vol. 35, no. 3, pp. 376-385, 2011. https://doi.org/10.1007/s11096-010-9449-y

[4] R. Wootton, K. Bahaadinbeigy, \& D. Hailey, "Estimating travel reduction associated with the use of telemedicine by patients and healthcare professionals: Proposal for quantitative synthesis in a systematic review," BMC Health Services Research, vol. 11, pp. 185-185, 2011. doi:10.1186/1472-6963-11-185. https://doi.org/10.1186/1472-6963-11-185

[5] B. Means, Y. Toyama, R. Murphy, M. Bakia, \& K. Jones, Evaluation of Evidence-Based Practices in Online Learning: A Meta-Analysis and Review of Online Learning Studies. Washington D.C: U.S Department of Education, 2009.

[6] E. Kaninnen, Learning Styles and E-Learning, Learning styles in virtual learning environments. Tampere: Tampere University of Technology, 2009.

[7] K. Fry, "E-learning markets and providers: some issues and prospects," Education + Training, vol. 43, no. 4/5, pp. 233-239, 2001. https://doi.org/10.1108/eum0000000005484.

[8] L. Kirtman, "Online versus in-class courses: An examination of differences in learning outcomes," Teacher Education, vol. 18, no. 2, pp. 103-116. 2009.

[9] J. W. You, \& M. Kang, "The role of academic emotions in the relationship between perceived academic control and self-regulated learning in online learning," Computers \&Education, vol. 77, pp. 125-133. 2014. https://doi.org/10.1016/j.compedu.2014.04.018

[10] S. Zimeras, \& L. G. Gortzis, "Interactive tele-radiological segmentation systems for treatment and diagnosis," International Journal of Telemedicine and Applications, vol. 2012, pp. 1 - 15, 2012. https://doi.org/10.1155/2012/713739

[11] I. Chorbev, M. Sotirovska, \& D. Mihajlov, "Virtual communities for diabetes chronic disease healthcare," International Journal of Telemedicine and Applications, vol. 2011, pp. 17. 2011. https://doi.org/10.1155/2011/721654

[12] C. Sorensen, "Classrooms without walls: A comparison of instructor performance in online courses differing in class size," MERLOT Journal of Online Learning and Teaching, vol. 10, no. 4, pp. 569-576, 2014 
[13] S. B. Smith, S. J. Smith, \& R. Boone, "Increasing access to teacher preparation: The effectiveness of traditional instructional methods in an online learning environment," Journal of Special Education Technology, vol. 15, no. 2, pp. 37-46, 2000. https://doi.org/10.1177/01 6264340001500204

[14] M. Gordon, J. Hodson, \& J. Kitchen, "Lessons learned: Effectiveness of courses developed for aboriginal teacher candidates delivered at a distance," International Journal of ELearning \& Distance Education, vol. 29, no. 2, pp. 1-24, 2014.

[15] M. Shonfeld \& L. Ronen, "Online learning for students from diverse backgrounds: Learning disability students, excellent students and average students," The IAFOR Journal of Education, vol. 3, no. 2, pp. 13-29, 2015. https://doi.org/10.22492/ije.3.2.01

[16] A. V. Fonolahi, M. G. M. Khan, \& A. Jokhan, "Are students studying in the online mode faring as well as students studying in the face-to-face mode? Has equivalence in learning been achieved?" Merlot Journal of Online Learning and Teaching, vol. 10, no. 4, pp. 598609, 2014.

[17] Y.H. Ching, \& Y. C. Hsu, “Online graduate students' preferences of discussion modality: Does gender matter?" Merlot Journal of Online Learning and Teaching, vol. 11, no. 1, pp. 31-41, 2015.

[18] J. M. Matuga, "Self-regulation, goal orientation, and academic achievement of secondary students in online university courses," Journal of Educational Technology \& Society, vol. 12, no. 3, 2009.

[19] W. C. Savenye, "Improving online courses: What is interaction and why use it? (Undetermined)," Distance Learning, vol. 2, no. 6, pp. 22-28, 2005.

[20] M. Kebritchi, A. Lipschuetz, \& L. Santiague, "Issues and challenges for teaching successful online courses in higher education: A literature review," Journal of Educational Technology Systems, vol. 46, no. 1, pp. 4-29, 2017. https://doi.org/10.1177/0047239516661713

[21] C. Li, \& B. Irby, "An Overview of online education: Attractiveness, benefits, challenges, concerns, and recommendations," College Student Journal, Part A, vol. 42, pp. 449-458, 2008.

[22] M. Hung, C. Chou, C. Chen, \& Z. Own, "Learner readiness for online learning: Scale development and student perceptions," Computers \& Education, vol. 55, pp. 1080-1090, 2010. https://doi.org/10.1016/j.compedu.2010.05.004

[23] P. J. Smith, K. L. Murphy, \& S. E. Mahoney, "Towards identifying factors underlying readiness for online learning: An exploratory study," Distance Education, vol. 24, pp. 5767, 2003. https://doi.org/10.1080/01587910303043

[24] H. Peng, C. C. Tsai, \& Y. T. Wu, "University students' self-efficacy and their attitudes toward the Internet: The role of students' perceptions of the Internet," Educational Studies, vol. 32, pp. 73-86, 2006. https://doi.org/10.1080/03055690500416025

[25] C.-C. Tsai, \& C.-C. Lin, "Taiwanese adolescents' perceptions and attitudes regarding the Internet: Exploring gender differences,” Adolescence, vol. 39, pp. 725-734, 2004.

[26] I. Luyt, "Bridging spaces: Cross-cultural perspectives on promoting positive online learning experiences," Journal of Educational Technology Systems, vol. 42, no. 1, pp. 3 - 20, 2013. https://doi.org/10.2190/et.42.1.b

[27] J. R. Hill, "Overcoming obstacles and creating connections: Community building in webbased learning environments," Journal of Computing in Higher Education, vol. 14, pp. 6786, 2002. https://doi.org/10.1007/bf02940951

[28] A. R. Roper, "How students develop online learning skills," Educause Quarterly, vol. 30, pp. 62-64, 2007.

[29] J. M. McInnery, \& T. S. Roberts, "Online learning: Social interaction and the creation of a sense of community," Educational Technology \& Society, vol. 7, pp. 73-81, 2004. 
[30] M. Koole, "Identity and the itinerant online learner," The International Review of Research in Open and Distance Learning, vol. 15, pp. 52-70, 2014.

[31] J. C. Lapadat, "Discourse devices used to establish community, increase coherence, and negotiate agreement in an online university course," International Journal of E-learning \& Distance Education, vol. 11, pp. 59-92, 2007.

[32] S. Hrastinski, "A theory of online learning as online participation," Computers \& Education, vol. 52, pp. 78-82, 2009. https://doi.org/10.1016/j.compedu.2008.06.009

[33] A. F. Wise, J. Speer, F. Marbouti, \& Y. Hsiao, "Broadening the notion of participation in online discussions: Examining patterns in learners' online listening behaviors," Instructional Science, vol. 41, pp. 323-343, 2013. https://doi.org/10.1007/s11251-012-9230-9

[34] H. H. Muljo, A. S. Perbangsa \& B. Pardamean, "Online learning content and learning management system for early detection of cervical cancer," International Journal of Digital Content Technology and its Applications, vol. 9, no. 1, pp. 54-63, 2015.

[35] H. H. Muljo, B. Pardamean \& A. S. Perbangsa, "The implementation of online learning for early detection of cervical cancer," Journal of Computer Sciences, vol. 13, no. 11, pp. 600607, 2017. https://doi.org/10.3844/jessp.2017.600.607

[36] C. Hall, "Lighting a fire or filling a pail? Users' perceptions of a virtual learning environment," Survey Report, University of Swansea, 2006. Retrieved 10 March 2016, from http://learninglab.swan.ac.uk/Downloads/User_Survey Report\%201.1.pdf.

[37] R. G. Saade, F. Nabebe \& W. Tan, "Viability of the 'Technology acceptance model' in multimedia learning environments: A comparative study," Interdisciplinary Journal of Knowledge and Learning Objects, vol. 3, no. 1, pp. 175-184, 2007. https://doi.org/ $\underline{10.28945 / 392}$

[38] F. D. Davis, "Perceived usefulness, perceived ease of use, and user acceptance of information technology," MIS Quarterly, vol. 13, no. 3, pp. 319-339, 1989. https://doi.org/10.23 $\underline{07 / 249008}$

\section{$7 \quad$ Authors}

Hery Harjono Muljo is a researcher at Bioinformatics \& Data Science Research Center and a lecturer at Accounting Program, Bina Nusantara University, Jakarta Indonesia. His research expertise is in developing management information system of health institutions such as hospitals and clinics.

Anzaludin Samsinga Perbangsa is a researcher at Bioinformatics \& Data Science Research Center and a lecturer at School of Information Systems, Bina Nusantara University, Jakarta, Indonesia. His research expertise is in developing tools to investigate the interplay of genetic and environmental factors in agriculture and has developed agricultural germplasm database.

Bens Pardamean is Director of Bioinformatics \& Data Science Research Center and Associate Professor of Computer Science, Bina Nusantara University, Jakarta, Indonesia. His research expertise is in information technology, bioinformatics, and education, including a strong background in database systems, computer networks, and quantitative research.

Article submitted 2019-05-29. Resubmitted 2019-06-25. Final acceptance 2019-07-03. Final version published as submitted by the authors. 